\title{
Effect of Integrated Nutrient Management on Growth and Yield Attributes of Summer Pearl Millet in South Gujarat
}

\author{
M. B. Khadadiya ${ }^{1}$, A. P. Patel ${ }^{2 *}$ and V. T. Shinde ${ }^{3}$ \\ ${ }^{1}$ N. M. College of Agriculture, NAU, Navsari, Gujarat, India \\ ${ }^{2}$ Department of Agronomy, ${ }^{3}$ Department of Soil \& Water Engineering, College of Agriculture, \\ NAU, Waghai, Gujarat, India \\ *Corresponding author
}

\section{A B S T R A C T}

\section{Keywords}

Ear head girth (5.53

$\mathrm{cm})$, Test weight

(12.70 g), Grain yield $(5035 \mathrm{~kg} / \mathrm{ha})$

Article Info

Accepted:

12 November 2019

Available Online:

10 December 2019
A field experiment was conducted during summer season of 2018 at college farm of N. M. College of Agriculture, Navsari, Gujarat, to study the effect of integrated nutrient management on summer pearl millet under south Gujarat conditions. Two levels of manure (no compost and vermicompost @ 10 t/ha), three fertilizer levels (no RDF, 75 per cent RDF and 100 per cent RDF) and two levels of biofertilizer (no seed inoculation and seed inoculation with Azotobacter @ $2 \mathrm{ml} / \mathrm{kg}$ seeds) were compared. Application of 10 tonnes vermicompost/ha significantly increased plant height at 30,60 DAS and at harvest (23.68, 90.79 and $166.23 \mathrm{~cm}$, respectively), dry matter accumulation at 30, 60 DAS and at harvest (24.21, 45.18 and $53.54 \mathrm{~g} /$ plant, respectively), number of effective tillers (3.76), ear head length $(19.20 \mathrm{~cm})$, ear head girth $(5.53 \mathrm{~cm})$, test weight $(12.70 \mathrm{~g})$, grain yield $(5035 \mathrm{~kg} / \mathrm{ha})$ and straw yield (11134 kg/ha) over control. Improvement in plant height at 30, 60 DAS and at harvest $(23.20,88.28$ and $161.17 \mathrm{~cm}$, respectively), dry matter accumulation at 30, 60 DAS and at harvest (22.02, 41.84 and $49.16 \mathrm{~g} /$ plant, respectively), number of effective tillers (3.33), ear head length $(18.73 \mathrm{~cm})$, ear head girth $(5.48 \mathrm{~cm})$, test weight $(12.45 \mathrm{~g})$, grain yield (4310 kg/ha) and straw yield (9479 kg/ha) were also noticed with 100 per cent RDF. Seed inoculation with Azotobacter also increased plant height at 30,60 DAS and at harvest $(22.65,87.31$ and $160.17 \mathrm{~cm}$, respectively), dry matter accumulation at 30, 60 DAS and at harvest (19.96, 39.31 and $46.97 \mathrm{~g} /$ plant, respectively), number of effective tillers $(3.21)$, ear head length $(18.05 \mathrm{~cm})$, ear head girth $(5.41 \mathrm{~cm})$, test weight $(12.37 \mathrm{~g})$, grain yield (3904 kg/ha) and straw yield (8704 kg/ha) over control.

\section{Introduction}

Pearlmillet (Pennisetum glaucum L.) is one of the important millet crops of India. Among the millets, it comes next to sorghum in area and production. Rajasthan ranks first in area and production of pearlmillet. Besides being a staple diet of about 10 per cent population of our country, it is an important fodder crop also. It is the only cereal crop that is capable 
of producing a reliable yield under the marginal environments and simultaneously responds to high management conditions. Its nutritious grain forms the important component of human diet and stover forms the principal maintenance ration for ruminant livestock during the dry poultry. It is nutritionally better than many cereals as it is a good source of protein (12.6 per cent), minerals, particularly iron ( 2.8 per cent $)$ and fat (5 per cent). In India, it is annually grown on 8.74 million ha area producing nearly 8.83 million tonnes of grains with productivity of $1011 \mathrm{~kg} \mathrm{ha}^{-1}$ (Anon., 2011).

\section{Materials and Methods}

In order to accomplish the objectives, the present field experiment entitled, "Effect of integrated nutrient management in summer pearlmillet (Pennisetum glaucum L.) under south Gujarat condition" was conducted during summer season of 2018 at the College Farm, N. M. College of Agriculture, Navsari Agricultural University, Navsari. The campus is geographically located at $20^{\circ}-57^{\prime} \mathrm{N}$ latitude and $72^{\circ}-54^{\prime} \mathrm{E}$ longitude at an altitude of 10 meters above the mean sea level. According to agro-climatic conditions, Navsari is located in south Gujarat heavy rainfall zone-I (Agroecological situation-III). The climate of this zone is typically tropical, characterized by humid and warm monsoon with heavy rain, quite cold winter and fairly hot summer. The average annual rainfall of the tract is about $1500 \mathrm{~mm}$. The soil of experimental field was clayey in texture, having $\mathrm{pH} 7.8$ with normal electrical conductivity $\left(0.36 \mathrm{dsm}^{-1}\right)$, low in organic carbon content $(0.72 \%)$, low in available nitrogen $\left(150.23 \mathrm{~kg} \mathrm{ha}^{-1}\right)$, medium in available phosphorus (49 $\left.\mathrm{kg} \mathrm{ha}^{-1}\right)$ and fairly rich in available potassium $\left(307.81 \mathrm{~kg} \mathrm{ha}^{-1}\right)$.

The treatments consisted of two levels of manure (no compost and vermicompost @ 10 t/ha), three fertilizer levels (no RDF, 75 per cent RDF and 100 per cent RDF) and two levels of biofertilizer (no seed inoculation and seed inoculation with Azotobacter @ $2 \mathrm{ml} / \mathrm{kg}$ seeds). These treatments were evaluated in randomized block design with factorial concept (FRBD) and replicate three times. Pearlmillet variety GCH-732 was sown in furrows at $45 \mathrm{~cm}$ row spacing using a seed rate of $3.75 \mathrm{~kg} / \mathrm{ha}$. Application of fertilizers (120:60:00 NPK kg/ha) was applied as per treatment. Half dose of $\mathrm{N}$ and full dose of $\mathrm{P}$ and $\mathrm{K}$ applied basal at the time of sowing and remaining half dose of $\mathrm{N}$ at 30 and 60 days after sowing. Vermicompost $(1.74 \% \mathrm{~N}, 0.89$ $\% \mathrm{P}, 0.86 \% \mathrm{~K}$ and 12:1 C: $\mathrm{N}$ ration) was mixed in soil at the time of field preparation as per treatment. Seed was uniformly coated with Azotobacter @ $2 \mathrm{ml} / \mathrm{kg}$ seeds as per treatments. The results were analysed using standard statistical procedure given by Panse and Sukhatme (1985).

\section{Results and Discussion}

\section{Manure}

Significant effect of vermicompost was observed on growth attributes, yield and yield attributes of pearlmillet. An application of vermicompost @ 10 tonnes/ha significantly increased plant heigtht at 30,60 DAS and at harvest $(23.68,90.79$ and $166.23 \mathrm{~cm}$, respectively), dry matter accumulation at 30 , 60 DAS and at harvest (24.21, 45.18 and $53.54 \mathrm{~g} /$ plant, respectively), number of effective tillers per plant (3.76), ear head length $(19.20 \mathrm{~cm})$, ear head girth $(5.53 \mathrm{~cm})$, test weight $(12.70 \mathrm{~g})$, grain yield $(5035 \mathrm{~kg} / \mathrm{ha})$ and straw yield (11134 kg/ha).Increase in these growth parameters has evidently resulted from favorable function on manure. The basic fact is that vermicompost provides secondary elements like $\mathrm{Ca}, \mathrm{Mg}$, and $\mathrm{S}$ and fairly high amounts of micronutrients to the plants. It also increases CEC, water holding capacity and phosphate availability in the soil. Thus 
balanced nutrition due to release of macro and micro nutrients due to application of vermicompost under favorable environment might have helped in higher uptake of nutrients. This accelerated the growth of new tissues and development of new shoots that have ultimately increased the plant height and dry mater accumulation. The results of present investigation are in conformity with those of Narolia et al., (2009), Jadhav et al., (2011), Chaudhary et al., (2014) and Kumar et al., $\left(2014^{\mathrm{a}}\right)$ in pearlmillet (Table 1-8).

Table.1 Interaction effect of manure and fertilizer on plant height of pearl millet

\begin{tabular}{|c|c|c|c|}
\hline Treatment & \multicolumn{3}{|c|}{ Plant height at harvest (cm) } \\
\hline & \multicolumn{3}{|c|}{ Fertilizer (F) } \\
\hline Manure (M) & $\mathbf{F}_{\mathbf{1}}$ & $\mathbf{F}_{\mathbf{2}}$ & $\mathbf{F}_{\mathbf{3}}$ \\
\hline $\mathbf{M}_{\mathbf{1}}$ & 133.41 & 156.12 & 145.53 \\
\hline $\mathbf{M}_{\mathbf{2}}$ & 157.74 & 164.13 & 176.81 \\
\hline S .Em. \pm & & 4.55 & \\
\hline C.D. at 5\% & & 33.33 \\
\hline
\end{tabular}

Table.2 Effect of integrated nutrient management on growth attributes of pearl millet

\begin{tabular}{|c|c|c|c|c|c|c|}
\hline \multirow[t]{2}{*}{ Treatments } & \multicolumn{3}{|c|}{ Plant height (cm) } & \multicolumn{3}{|c|}{$\begin{array}{c}\text { Dry matter accumulation } \\
\text { (g/plant) }\end{array}$} \\
\hline & $\begin{array}{l}\text { At } 30 \\
\text { DAS }\end{array}$ & $\begin{array}{l}\text { At } 60 \\
\text { DAS }\end{array}$ & $\begin{array}{c}\text { At } \\
\text { harvest }\end{array}$ & $\begin{array}{l}\text { At } 30 \\
\text { DAS }\end{array}$ & $\begin{array}{l}\text { At } 60 \\
\text { DAS }\end{array}$ & $\begin{array}{c}\text { At } \\
\text { harvest }\end{array}$ \\
\hline \multicolumn{7}{|c|}{ (A) Manure (M) } \\
\hline No compost (M1) & 21.11 & 78.98 & 145.02 & 14.65 & 27.75 & 34.83 \\
\hline $\begin{array}{c}\text { Vermicompost @ } 10 \text { t/ha } \\
\text { (M2) }\end{array}$ & 23.68 & 90.79 & 166.23 & 24.21 & 45.18 & 53.54 \\
\hline S.Em. + & 0.42 & 1.61 & 2.62 & 0.43 & 0.87 & 0.97 \\
\hline C.D. at 5\% & 1.24 & 4.74 & 7.70 & 1.25 & 2.55 & 2.86 \\
\hline \multicolumn{7}{|c|}{ (B) Fertilizer (F) } \\
\hline No RDF (F1) & 21.33 & 79.91 & 145.58 & 14.66 & 28.75 & 36.23 \\
\hline 75 per cent $\mathrm{RDF}$ (F2) & 22.66 & 86.46 & 160.12 & 21.61 & 38.81 & 47.16 \\
\hline 100 Per cent RDF (F3) & 23.20 & 88.28 & 161.17 & 22.02 & 41.84 & 49.16 \\
\hline S.Em. + & 0.52 & 1.98 & 3.21 & 0.52 & 1.07 & 1.19 \\
\hline C.D. at $5 \%$ & 1.52 & 5.80 & 9.43 & 1.54 & 3.13 & 3.50 \\
\hline \multicolumn{7}{|c|}{ (C) Biofertilizer (B) } \\
\hline No seed inoculation (B1) & 22.14 & 82.46 & 151.07 & 18.91 & 33.62 & 41.40 \\
\hline $\begin{array}{l}\text { Seed inoculation with } \\
\text { Azotobacter (B2) }\end{array}$ & 22.65 & 87.31 & 160.17 & 19.96 & 39.31 & 46.97 \\
\hline S.Em. + & 0.42 & 1.61 & 2.62 & 0.43 & 0.87 & 0.97 \\
\hline C.D. at 5\% & NS & 4.74 & 7.70 & NS & 2.55 & 2.86 \\
\hline
\end{tabular}


Table.3 Effect of integrated nutrient management on yield and yield attributes of pearl millet

\begin{tabular}{|c|c|c|c|c|c|c|}
\hline Treatments & $\begin{array}{c}\text { No. of } \\
\text { effective } \\
\text { tillers per } \\
\text { plant } \\
\end{array}$ & $\begin{array}{l}\text { Ear head } \\
\text { length } \\
(\mathrm{cm})\end{array}$ & $\begin{array}{l}\text { Ear head } \\
\text { girth } \\
(\mathrm{cm})\end{array}$ & $\begin{array}{c}\text { Test } \\
\text { weight } \\
\text { (g) }\end{array}$ & $\begin{array}{l}\text { Grain } \\
\text { yield } \\
\text { (kg/ha) }\end{array}$ & $\begin{array}{c}\text { Straw } \\
\text { yield } \\
\text { (kg/ha) }\end{array}$ \\
\hline \multicolumn{7}{|c|}{ (A) Manure (M) } \\
\hline No compost (M1) & 2.05 & 15.73 & 5.06 & 9.41 & 2215 & 5329 \\
\hline $\begin{array}{c}\text { Vermicompost @ } \\
10 \text { t/ha (M2) }\end{array}$ & 3.76 & 19.20 & 5.53 & 12.70 & 5035 & 11134 \\
\hline S.Em. + & 0.077 & 0.38 & 0.08 & 0.28 & 78.43 & 197.65 \\
\hline C.D. at $5 \%$ & 0.23 & 1.12 & 0.24 & 0.83 & 230.04 & 579.70 \\
\hline \multicolumn{7}{|c|}{ (B) Fertilizer (F) } \\
\hline No RDF (F1) & 2.30 & 16.16 & 5.09 & 9.52 & 2505 & 6091 \\
\hline $\begin{array}{c}75 \text { per cent RDF } \\
\text { (F2) }\end{array}$ & 3.10 & 17.51 & 5.32 & 11.20 & 4060 & 9125 \\
\hline $\begin{array}{l}100 \text { Per cent RDF } \\
\text { (F3) }\end{array}$ & 3.33 & 18.73 & 5.48 & 12.45 & 4310 & 9479 \\
\hline S.Em. + & 0.094 & 0.47 & 0.10 & 0.35 & 96.06 & 242.08 \\
\hline C.D. at $5 \%$ & 0.28 & 1.35 & 0.29 & 1.01 & 281.74 & 709.98 \\
\hline \multicolumn{7}{|c|}{ (C) Biofertilizer (B) } \\
\hline $\begin{array}{c}\text { No seed } \\
\text { inoculation (B1) }\end{array}$ & 2.60 & 16.88 & 5.17 & 9.74 & 3346 & 7760 \\
\hline $\begin{array}{l}\text { Seed inoculation } \\
\text { with Azotobacter } \\
\text { (B2) }\end{array}$ & 3.21 & 18.05 & 5.41 & 12.37 & 3904 & 8704 \\
\hline S.Em. + & 0.077 & 0.38 & 0.08 & 0.28 & 78.43 & 197.65 \\
\hline C.D. at $5 \%$ & 0.23 & 1.12 & 0.24 & 0.83 & 230.43 & 579.70 \\
\hline
\end{tabular}

Table.4 Interaction effect of manure and fertilizer on dry matter accumulation of pearl millet

\begin{tabular}{|c|c|c|c|}
\hline Treatment & \multirow{2}{*}{\multicolumn{3}{|c|}{$\begin{array}{c}\begin{array}{c}\text { Dry matter accumulation } \\
\text { (g/plant) }\end{array} \\
\text { Fertilizer }(\mathbf{F})\end{array}$}} \\
\hline & & & \\
\hline $\begin{array}{c}\text { Manure } \\
\text { (M) }\end{array}$ & $\mathbf{F}_{1}$ & $\mathbf{F}_{2}$ & $\mathbf{F}_{3}$ \\
\hline $\mathbf{M}_{1}$ & 24.44 & 39.71 & 40.34 \\
\hline $\mathbf{M}_{2}$ & 48.02 & 54.62 & 57.98 \\
\hline S.Em. \pm & \multicolumn{3}{|c|}{1.69} \\
\hline C.D. at $5 \%$ & \multicolumn{3}{|c|}{4.95} \\
\hline
\end{tabular}


Table.5 Interaction effect of manure and fertilizer on number of effective tillers of pearl millet

\begin{tabular}{|c|c|c|c|}
\hline Treatment & \multicolumn{3}{|c|}{$\begin{array}{c}\text { Number of effective tillers } \\
\text { per plant }\end{array}$} \\
\hline & \multicolumn{3}{|c|}{ Fertilizer (F) } \\
\hline $\begin{array}{c}\text { Manure } \\
\text { (M) }\end{array}$ & $\mathbf{F}_{\mathbf{1}}$ & $\mathbf{F}_{\mathbf{2}}$ & $\mathbf{F}_{\mathbf{3}}$ \\
\hline $\mathbf{M}_{\mathbf{1}}$ & 1.64 & 2.07 & 2.45 \\
\hline $\mathbf{M}_{\mathbf{2}}$ & 2.95 & 4.14 & 4.20 \\
\hline S .Em. $\mathbf{\pm}$ & & 0.13 & \\
\hline C.D. at 5\% & & 0.39 \\
\hline
\end{tabular}

Table.6 Interaction effect of manure and fertilizer on ear head length of pearl millet

\begin{tabular}{|c|c|c|c|}
\hline Treatment & \multicolumn{3}{|c|}{ Ear head length (cm) } \\
\hline & \multicolumn{3}{|c|}{ Fertilizer (F) } \\
\hline $\begin{array}{c}\text { Manure } \\
\text { (M) }\end{array}$ & F $_{\mathbf{1}}$ & $\mathbf{F}_{\mathbf{2}}$ & $\mathbf{F}_{\mathbf{3}}$ \\
\hline $\mathbf{M}_{\mathbf{1}}$ & 15.21 & 15.93 & 16.06 \\
\hline $\mathbf{M}_{\mathbf{2}}$ & 17.11 & 19.10 & 21.39 \\
\hline S.Em. \pm & & 0.66 & \\
\hline C.D. at 5\% & & 1.94 \\
\hline
\end{tabular}

Table.7 Interaction effect of manure and fertilizer on grain yield of pearl millet

\begin{tabular}{|c|c|c|c|}
\hline Treatment & \multicolumn{3}{|c|}{ Grain yield (kg/ha) } \\
\hline $\begin{array}{c}\text { Manure } \\
\text { (M) }\end{array}$ & Fertilizer (F) $_{\mathbf{1}}$ & $\mathbf{F}_{\mathbf{2}}$ & $\mathbf{F}_{\mathbf{3}}$ \\
\hline $\mathbf{M}_{\mathbf{1}}$ & 1449 & 2447 & 2749 \\
\hline $\mathbf{M}_{\mathbf{2}}$ & 3561 & 5672 & 5871 \\
\hline S.Em. \pm & \multicolumn{3}{|c|}{135.85} \\
\hline C.D. at 5\% & \multicolumn{3}{|c}{398.44} \\
\hline
\end{tabular}

Table.8 Interaction effect of manure and fertilizer on straw yield of pearl millet

\begin{tabular}{|c|c|c|c|}
\hline Treatment & \multicolumn{3}{|c|}{ Straw yield (kg/ha) } \\
\hline & \multicolumn{3}{|c|}{ Fertilizer (F) } \\
\hline $\begin{array}{c}\text { Manure } \\
\text { (M) }\end{array}$ & F $_{\mathbf{1}}$ & $\mathbf{F}_{\mathbf{2}}$ & $\mathbf{F}_{\mathbf{3}}$ \\
\hline $\mathbf{M}_{\mathbf{1}}$ & 3846 & 5742 & 6399 \\
\hline $\mathbf{M}_{\mathbf{2}}$ & 8337 & 12507 & 12560 \\
\hline S.Em. $\mathbf{\pm}$ & \multicolumn{3}{|c|}{342.35} \\
\hline C.D. at 5\% & \multicolumn{3}{|c}{1004.07} \\
\hline
\end{tabular}


The higher values of yield attributes like number of effective tillers per plant, ear head length and girth and test weight coupled with the higher crop dry matter observed with these treatments might have been the most probable reason of higher grain yield. The increase in grain yield of pearlmillet with these treatments was also largely due to high harvest index that showed high partitioning of the plant assimilates towards the sink. Similar results were also obtained by Chaudhary et al., (2012) in pearlmillet, Anon. (2013) in pearlmillet, Chaudhary et al., (2015) in pearlmillet and Biri et al., (2016) in sorghum.

\section{Fertilizer}

Successive levels of fertilizer significantly increased the growth attributes, yield and yield attributes. Significantly highest plant height at 30,60 DAS and at harvest $(23.20,88.28$ and $161.17 \mathrm{~cm}$, respectively), dry matter accumulation at 30,60 DAS and at harvest (22.02, 41.84 and $49.16 \mathrm{~g} / \mathrm{plant}$, respectively), number of effective tillers per plant (3.33), ear head length $(18.73 \mathrm{~cm})$, ear head girth $(5.48$ $\mathrm{cm})$, test weight (12.45 g), grain yield (4310 $\mathrm{kg} / \mathrm{ha}$ ) and straw yield (9479 $\mathrm{kg} / \mathrm{ha})$ was recorded in treatment receiving $100 \% \mathrm{RDF}$, while the lowest in the control. The reason for better growth and development under these treatments might be the increased availability of nutrients to plant through inorganic fertilizers matching to the need of crop throughout the growing season. Being a cereal crop, pearlmillet required nutrients throughout the growing season. The results obtained in the present investigation are in close conformity with the finding of Rathore et al., (2006), Narolia and Poonia (2011), Kumar et al., (2014b), Singh and Chauhan (2016) and Patel et al., (2018) in pearlmillet, Singh et al., (2017) in maize and Patidar and Mali (2004), Panwar et al.,(2014) in sorghum.

Further, $\mathrm{P}_{2} \mathrm{O}_{5}$ fertilization also improves the metabolic and physiological processes and thus known as "energy currency" which is subsequently used for vegetative and reproductive growth through phosphorylation. In addition to vital metabolic role, $\mathrm{P}$ is an important structural component of nucleic acid, phytein, phospholipids and enzymes. An adequate supply of phosphorous early in the life cycle of plant is important in laying down the primordia of its reproductive part. The present findings are in close confirmation with those of Rathore et al., (2006), Chaudhary et al., (2015), Patel et al., (2018), Varia and Sadhu (2012) in pearlmillet, Khan et al., (2015) in sweet sorghum in pearlmillet.

\section{Biofertilizer}

Plant height at 30 DAS and dry matter accumulation per plant at 30 DAS in pearl millet remained unaffected due to inoculation of biofertilizers. Highest plant height at 60 DAS and at harvest $(87.31$ and $160.17 \mathrm{~cm}$, respectively), dry matter accumulation at 60 DAS and at harvest (39.31 and $46.97 \mathrm{~g} / \mathrm{plant}$, respectively), number of effective tillers per plant (3.21), ear head length $(5.41 \mathrm{~cm})$, ear head girth $(18.05 \mathrm{~cm})$, test weight $(12.37 \mathrm{~g})$, grain yield (3904 kg/ha) and straw yield (8704 $\mathrm{kg} / \mathrm{ha}$ ) was recorded with the seed inoculation with Azotobacter.

Increased growth and yield under the influence of Azotobacter inoculation might be due to the increased number of efficient and healthy strain of Azotobacter in the rhizosphere, which in turn resulted in better utilization of atmospheric nitrogen. These results are in close conformity with the findings of Patel et al., (2014), Rinku et al., (2014) in pearlmillet and Patel et al., (1992), Agrawal et al., (1996) in fodder sorghum.

\section{Interaction}

Application of vermicompost @ 10 tonnes/ha with 100 per cent RDF resulted in maximum plant height at harvest $(176.81 \mathrm{~cm})$ and dry 
matter accumulation per plant at harvest (57.98 g) of pearl millet, being at par with vermicompost and 75 per cent RDF. The reason for better growth and development under these treatments might be the increased availability of nutrients to plant initially through inorganic fertilizers and then by organic manures like vermicompost matching to the need of crop throughout the growing season. Being a cereal crop, pearlmillet required nutrients throughout the growing season. Louraduraj (2006) in maize reported similar results from their experiments.

Application of vermincompost @ 10 tonnes/ha with 100 per cent RDF resulted in maximum grain yield $(5871 \mathrm{~kg} / \mathrm{ha})$, straw yield $(12560$ $\mathrm{kg} / \mathrm{ha}$ ), number of effective tillers per plant (4.20), ear head length $(21.39 \mathrm{~cm})$ of pearlmillet, being at par with vermicompost and 75 per cent RDF in case of all yield attributes and yield except ear head length. This indicates that use of vermicompost in combination with fertility levels has beneficial effect in improving the crop yield. The beneficial response of vermicompost to yield might also be attributed to the better availability of sufficient amounts of plant nutrients throughout the growth period and especially at critical growth period of crops which has resulted in better plant vigour and superior yield attributes. These results are in line of the result of those reported by Divya et al., (2017) in pearlmillet, Singh et al., (2017) in maize, Sheoran and Rana (2005) in sorghum, Pawar and Patil (2007) in maize, Govindappa et al., (2009) in finger millet and Chaudhary et al., (2014), Shrivastava and Arya (2017, Jain et al., (2018) in pearlmillet.

It could be concluded that application of vermicompost @ 10 tonnes/ha with 100 per cent RDF and inoculation of Azotobacter improved growth attributes, yield and yield attributes in pearl millet under the prevailing agro-climatic condition.

\section{References}

Agrawal, S. B., Dubey, K., Thakur, G. S. and Dubey, R. K. (1996). Saving of nitrogen by Azotobacter inoculation in forage sorghum (Sorghum bicolor L. Moench). Advances Agric. Res. India., 5: 52-54.

Anonymous (2011). Area and production of pearl millet in India. Agricultural Statistics, Directorate of Economics and Statistics, Govt. of India

Anonymous (2013). AGRESCO report of crop production of AAU, Anand presented 9th meeting of combined joint AGRESCO of SAU's at SDAU, Sardar krushinagar. pp. 39-42.

Biri, A., Kaba, S., Taddesse, F., Dechassa, N., Sharma, J. J., Zewidie, A. and Chavhan, A. (2016). Effect of vermicompost and nitrogen application on striga incidence, growth, and yield of sorghum [Sorghum bicolor L. monech] in Fedis, Eastern Ethiopia. International Journal of Life Sciences, 4(3): 349-360.

Choudhary, R., Yadav, L. R. and Parihar, S. (2014). Studies on the interactive effect between vermicompost and fertility levels on pearl millet (Pennisetum glaucum L.). Annals of Agri-Bio Research, 19 (3): 430-433.

Choudhary, R., Yadav, L. R. and Parihar, S. (2015). Effect of vermicompost and fertility levels on growth and yield of pearl millet (Pennisetum glaucum L.). Annals of Arid Zone, 54(1\&2): 59-61.

Choudhary, R., Yadav, L. R., Shivran, A. C. and Parihar, S. (2012). Effect of vermicompost and fertility levels on growth, yield, nutrient uptake and net returns in pearlmillet (Pennisetum glaucum). Indian Journal of Agricultural Sciences, 8: 1428-1430.

Divya, G., Vani, K. P., Babu, P. S. and Suneetha Devi, K. B. (2017). Yield 
attributes and yield of summer pearlmillet as influenced by cultivars and integrated nutrient management. International Journal of Current Microbiology and Applied Sciences, 6(10): 1491-1495.

Govindappa, M., Vishwanath, A. P., Harsha, K. N., Thimmegowda, P. and Jnanesh, A. C. (2009). Response of fingermillet (Eluesine coracana L.) to organic and inorganic sources of nutrients under rainfed condition. Journal of Crop and Weed, 5(1): 291-293.

Jadhav, R. P., Khafi, H. R. and Raj, A. D. (2011). Effect of nitrogen and vermicompost on protein content and nutrients uptake in pearlmillet (Pennisetum glaucum (L.) R. Br. Emend stuntz.). Agricultural Science Digest, 31 (4): 319-321.

Jain, A. K., Shrivastava, S. and Arya, V. (2018). Response of organic manure, zinc and iron on soil properties, yield and nutrient uptake by pearlmillet crop grown in Inceptisol. International Journal of Pure and Applied Bioscience, 6(1): 426-435.

Khan, M. A. A., Rajesh, P., Reddy, A. P. K. and Krishna, A. (2015). Nutrient management in different millet crops under pongomia based agrisilvi system in semi-arid region of Telangana Stat, India. International Journal of Tropical Agriculture, 33(2): 16611667.

Kumar, P., Kumar, R., Singh, S. K. and Kumar, A. $\left(2014^{\mathrm{a}}\right)$. Effect of fertility on growth yield and yield attributes of pearl millet (Pennisetum glaucum L.) under rainfed condition. Agriways, 2 (2): 89-93.

Kumar, P., Singh, R., Singh, A., Paliwal, D. and Kumar, S. $\left(2014^{\mathrm{b}}\right)$. Integrated nutrient management in pearl millet (Pennisetum glaucum) - wheat (Triticum aestivum) cropping sequence in semi arid condition of India. International Journal of Agricultural Sciences, 10(1): 96-101.

Louraduraj, A. C. (2006). Identification of optimum quantity of vermicompost for maize under different levels of fertilization. Journal of Ecobiology, 18: 23-27.

Narolia, R. S. and Poonia, B. L (2011). Growth dynamics, yield and economics of pearl millet (Pennisetum glaucum) as influenced by vermicompost and fertilizers. Annals of Arid Zone, 50(2): 145-149.

Narolia, R. S., Poonia, B. L. and Yadav, R. S. (2009). Effect of vermicompost and inorganic fertilizers on productivity of pearl millet (Pennisetum glaucum). Indian Journal of Agriculture Science, 79: 506-509.

Panse, V. G. and Sukhatme, P. V. (1985). Statistical Method for Agricultural workers, I. C. A. R., New Delhi.

Panwar, D., Singh, P. and Sumeriya, H. K. (2014). Growth, dry matter partitioning and yield of sorghum [Sorghum bicolour (L) Moench] genotypes as influenced by different fertility levels. Annals of Biology, 30(3): 491-494.

Patel, P. C., Patel, J. R. and Sadhu, A. C. (1992). Response of forage sorghum (Sorghum bicolor) to bio-fertilizer and nitrogen levels. Indian J. Agron., 37 (3): 466-469.

Patel, P. R., Patel, B. J., Vyas, K. G. and Yadav, B. L. (2014). Effect of integrated nitrogen management and bio-fertilizer in Kharif pearlmillet (Pennisetum glaucum L.). Advance Research Journal of Crop Improvement, 5(2): 122-125.

Patel, S. A., Chaudhary, P. P., Chaudhary, N. and Chaudhary, H. L. (2018). Effect of wheat residue management and fertilizer levels on growth, yield attributes and yield of summer pearl 
millet [Pennisetum glaucum (L.) R. $\mathrm{Br}$.] under north Gujarat condition. Journal of Pharmacognosy and Phytochemistry, 7(6): 1292-1295.

Patidar, M. and Mali, A. L. (2004). Effect of farmyard manure, fertility levels and bio-fertilizers on growth, yield and quality of sorghum (Sorghum bicolor). Indian Journal of Agronomy, 49(2): 117-120.

Pawar, R. B. and Patil, C. V. (2007). Effect of vermicompost and fertilizer level on soil properties, yield and uptake of nutrients by maize. Journal of Maharashtra Agricultural University, 32(1): 11-14.

Rathore, V. S., Singh, P. and Gautam, R. C. (2006). Productivity and water-use efficiency of rainfed pearlmillet (Pennisetum glaucum) as influenced by planting patterns and integrated nutrient management. Indian Journal of Agronomy, 51(1): 46-48.

Rinku, Shekhawat, P. S., Kumawat, N., Rathore, P. S., Yadav, P. K. and Om, H. (2014).Effect of nitrogen levels and biofertilizers on growth and yield of pearl millet (Pennisetum glaucum L.) under north western Rajasthan. Ann. Agric. Res. New Series, 35 (3): 311314.

Sheoran, R. S. and Rana, D. S. (2005). Relative efficacy of vermicompost and farmyard manure integrated with inorganic fertilizers for sustainable productivity of sorghum (Sorghum bicolor L. Moench.). Acta Agronomica Hungarica, 53: 303-308.

Shrivastava, S. and Arya, V. (2017). Effect of integrated application of inorganic and organic sources of manures on test weight, length of earhead and available soil micronutrient under pearlmillet crop. International Journal of Pure and Applied Bioscience, 5 (5): 720724.

Singh, L., Kumar, S., Singh, K. and Singh, D. (2017). Effect of integrated nutrient management on growth and yield attributes of maize under winter season (Zea mays L.) Journal of Pharmacognosy and Phytochemistry, 6(5): 1625-1628.

Singh, S. B. and Chauhan S. K. (2016). Effect of integrated nutrient management on pearl millet crop grown in semi-arid climate. TECHNOFAME- A Journal of Multidisciplinary Advance, 5(2): 5457.

Varia, S. D. and Sadhu, A. C. (2012). Influence of row ratios and fertility levels on yield attributes and yield of pearlmillet-greengram intercropping system and nutrient status of the soil. International Journal of Forestry and Crop Improvement, 3(2): 144-146.

\section{How to cite this article:}

Khadadiya, M. B., A. P. Patel and Shinde, V. T. 2019. Effect of Integrated Nutrient Management on Growth and Yield Attributes of Summer Pearl Millet in South Gujarat. Int.J.Curr.Microbiol.App.Sci. 8(12): 1637-1645. doi: https://doi.org/10.20546/ijcmas.2019.812.197 